\title{
Assessment of ability of medical and obstetric students to achieve adequate positive pressure ventilation using basic neonatal resuscitation manikins \\ Evaluación de la habilidad de los estudiantes de medicina y obstetricia para lograr una ventilación con presión positiva adecuada utilizando maniquíes básicos de reanimación neonatal
}

\author{
Blanca Solis-Chimoy ${ }^{1, a}$, Carlos A. Delgado ${ }^{1,2, b}$, Roberto Shimabuku ${ }^{1, c}$, Milagro Raffo ${ }^{1, d}$ \\ ${ }^{1}$ Research Group Neonatology, Department of Pediatrics, Faculty of Medicine, Universidad Nacional Mayor de San Marcos, Lima, Peru. \\ ${ }^{2}$ Department of Pediatrics, Neonatal Unit, Instituto Nacional de Salud del Niño. Lima, Perú \\ ${ }^{a}$ Medical Student, ORCID: https://orcid.org/0000-0002-0654-4645 \\ ${ }^{b}$ Medical Doctor, Professors of Pediatrics. ORCID: https://orcid.org/0000-0002-6073-8109 \\ ${ }^{c}$ Medical Doctor, Professors of Pediatrics. ORCID: https://orcid.org/0000-0001-6156-6786 \\ ${ }^{d}$ Medical Doctor, Professors of Pediatrics. ORCID: https://orcid.org/0000-0001-9954-6481
}

An Fac med. 2021;82(3):189-93. / DOI: https://doi.org/10.15381/anales.v82i3.20665

\section{Correspondencia:}

Carlos Alberto Delgado Bocanegra

cdelgadob1@unmsm.edu.pe

Received: 13 July 2021

Accepted: 8 October 2021

Online publication: 29 October 2021

Declaration of conflict of interest: No conflict of interest

Research funding: No external finance

Partially presented in the "Simpósio Internacional de Ressuscitação Neonatal" 05 to 07 April 2018 Foz do Iguaçu, Brazil. Available in Portuguese: $h$ ttp:/anais.sbp. com.br/trabalhos-de-congressos-dasbp/7-simpsio-internacional-de-reanimaoneonatal0004-competencias-deestudantes-de-obstetricia-para-a.pdf

Cite as: Solis-Chimoy B, Delgado A, Shimabuku R, Raffo M. Assessment of ability of medical and obstetric students to achieve adequate positive pressure ventilation using basic neonatal resuscitation manikins. An Fac med. 2021;82(3):189-93. DOI: https:/doi. org/10.15381/anales.v82i3.20665
Abstract

Introduction. The ability to perform adequate positive pressure ventilation is necessary for neonatal clinical practice. However, there are few studies on the achievements of undergraduate students on this task. It is necessary to assess health science students' adequate positive pressure ventilation because it is vital at the beginning of their clinical activity. Objective. To evaluate the cognitive and procedural ability related to adequate positive pressure ventilation performed by 6th year medicine students and 4 th year obstetrics students at a public university in Lima, Peru. Methods. We surveyed 78 medical and obstetric students in their last years of studies within six months of taking a course on neonatal resuscitation that included positive pressure ventilation theory and practice. Participants voluntarily agreed to participate in this study. Previously, we validated the survey by asking three experienced neonatologists for their expert judgments on improving the survey. The survey consists of three theoretical questions as a cognitive assessment and three practice assessment criteria qualified by observing performance using neonatal manikins. Results. Medicine students had a better practical ability $(p<0.001)$ than obstetrics students, and obstetrics students presented better theoretical knowledge $(p=0.019)$. However, both groups achieved limited performance within six months of taking the neonatal clinical practice course as $21.8 \%$ of all students passed both the theoretical and practical parts of this study. Conclusion. Participants from both schools require further training alternatives to achieve adequate positive pressure ventilation performance.

Keywords: Infant, Newborn; Cardiopulmonary Resuscitation; Intermittent Positive-Pressure Breathing; Students, Health Occupations; Simulation Training (source: MeSH NLM)

\section{Resumen}

Introducción. Una adecuada ventilación con presión positiva es necesaria para la práctica clínica neonatal. Sin embargo, pocos estudios describen los logros de estudiantes de pregrado en esta tarea. Es necesario evaluar la adecuada ventilación con presión positiva en los estudiantes de ciencias de la salud porque es una tarea vital al inicio de su actividad clínica. Objetivo. Evaluar habilidades cognitivas y procedimentales relacionadas con la adecuada ventilación con presión positiva de estudiantes del $6^{\circ}$ año de medicina y $4^{0}$ de obstetricia de una universidad pública de Lima, Perú. Métodos. Encuestamos a 78 estudiantes de medicina y obstetricia dentro de los seis meses posteriores a su curso sobre reanimación neonatal que incluia la teoria y la práctica de la ventilación con presión positiva. Los alumnos participaron voluntariamente en este estudio. Previamente, validamos la encuesta con la opinión de tres neonatólogos sobre cómo mejorarla. La encuesta consta de tres preguntas teóricas de evaluación cognitiva y tres criterios de evaluación práctica calificados mediante observación del desempeño en maniquíes. Resultados. Los estudiantes de medicina tuvieron mejor habilidad práctica $(p<0.001)$ y los estudiantes de obstetricia presentaron mejores conocimientos teóricos $(p=0.019)$. Sin embargo, ambos grupos lograron un rendimiento global limitado debido a que solamente el $21,8 \%$ de todos los estudiantes aprobaron simultáneamente las evaluaciones teórica y práctica de este estudio. Conclusión. Los participantes de ambas escuelas requieren más alternativas de entrenamiento para alcanzar un rendimiento adecuado en la realización de la ventilación con presión positiva en maniquies neonatales.

Palabras clave: Recién Nacido; Reanimación Cardiopulmonar; Respiración con Presión Positiva Intermitente; Estudiantes del Área de la Salud; Entrenamiento Simulado (fuente: DeCS - BIREME) 


\section{INTRODUCTION}

Neonatal resuscitation training improves neonatal resuscitation skills and teaching neonatal resuscitation to undergraduate health students is part of the academic training in the last years of their studies. Continuous neonatal resuscitation training strengthens the learning of skills designed to help a newborn in its first minutes of life.

The American Academy of Pediatrics (AAP) has developed different strategies for neonatal resuscitation training. For example, the "Helping Babies Survive" series of programs, including "Helping Babies Breathe" (HBB), contribute to reducing three root causes of neonatal mortality in low- and middle-income countries, including labor complications and preterm birth and neonatal infections (1). Both the HBB program and the AAP Neonatal Resuscitation Program (NRP) complement each other. However, the HBB is a simplified version of the AAP Neonatal Resuscitation Training Program (NRPAAP) ${ }^{(2)}$. The NRP-AAP is a comprehensive program and is an evidence-based pedagogical course framework consisting of the following six steps for training procedural skills to students: learn, see, practice, demonstrate, do, and maintain the taught skills ${ }^{(3,4)}$.

These programs currently use manikins, simulations, or interactive tools to conduct teaching or training for various scenarios ${ }^{(2)}$. All these programs improve learning and student performance (1-4). Nevertheless, it is still essential to assess training alternatives for this type of program in low- and middle-income countries. In Peru, where 33\% of neonatal deaths are preventable, even more so in urban areas or in the highlands, timely training could improve newborns' quality of care ${ }^{(5)}$

Research has shown that graduate and undergraduate health science students tend to perform poorly in neonatal resuscitation ${ }^{(6,7)}$. Decreased skills and knowledge are significant barriers to the success of neonatal resuscitation training programs. However, it is necessary to learn how to improve neonatal resuscitation training in medical schools. Above all, continuous training is required for adequate delivery room performance, and Positive Pressure Ventilation (PPV) is essential in most cases ${ }^{(5,6)}$. Continuous training and structured practice would allow better learning. The knowledge acquired from an NRP course is high, but the retention of these skills is short-term (7). Therefore, to achieve optimal performance, it is necessary to conduct more research to evaluate and implement improvements in both undergraduate and in-service training during graduates' clinical activity.

During 2018 and 2019, the Faculty of Medicine, Universidad Nacional Mayor de San Marcos (UNMSM) developed a virtual course and theoretical-practical workshops on neonatal resuscitation for students in the Schools of Human Medicine and Obstetrics. Nonetheless, the research problem is that this training's influence on health students' performance in the UNMSM is unknown. The present study evaluates the cognitive and procedural skills related to positive pressure ventilation for 6th-year medicine and 4th-year obstetrics students at a public university in Lima, Peru.

\section{METHODS}

The research conducted was descriptive with a cross-sectional design. The objective was to describe students' cognitive and procedural ability to achieve adequate positive pressure ventilation using neonatal manikins.

The sample was selected using convenience sampling. We assessed participants from the Schools of Obstetrics and Human Medicine by analyzing their ability to answer questions about PPV and perform effective PPV for basic neonatal resuscitation using training manikins. Previously, we validated the survey by requesting suggestions for improvements from three experienced neonatologists who provided expert judgments. The survey consists of three theoretical multiple-choice questions as a cognitive assessment of adequate PPV and three practical assessment criteria that are qualified by observing PPV performance using basic neonatal training manikins (Supplementary Material).

The descriptive analyses included central tendency and $\mathrm{Cl}$ (95\%) measures and Fisher's exact test for comparisons. All statistical analyses we performed using the Stata version 16 statistical software (Stata Corporation, College Station, TX, USA).

Participation was voluntary, and those who agreed to participate signed informed consent forms, which were reviewed by an institutional ethics committee. Professors requested students' participation in this research at the end of other academic activities not related to the resuscitation course. The professors' concern about influencing students' acceptance for participation was minimal because the neonatal course ended some months before. In all the study procedures, we preserve participants' integrity and fundamental rights, following the guidelines for biomedical research practices, including backing to autonomy and non-maleficence principles. An institutional ethics committee reviewed this proposal and manuscript. We guarantee the confidentiality of the obtained data.

\section{RESULTS}

A total of 78 students participated voluntarily, and $75.6 \%$ of the participants were women. We measured the theoretical and practical PPV performance of 36 4th year Obstetrics students and 42 6th year human medicine students at the UNMSM. Overall, 88 Obstetrics students and 163 Medicine students were enrolled, which gives $41 \%$ participation in Obstetrics and $26 \%$ in Medicine, respectively. The mean age of the obstetrics student participants was 23 years old (sd $=1.4$ ) and that of the medicine student participants was 27 years old ( $s d=4.8)$. In the evaluation, we did not find a difference in the participants when comparing males and females $(p=0.415)$.

Only 17 out of 78 students (21.8\%) passed both the theoretical and practical performance. Approximately 23\% of all students failed the theoretical assessment [ $\mathrm{Cl}$ 95\% $0.149-0.339]$, and 
$71.79 \%$ failed the practical assessment [Cl 95\% 0.606-0.808].

Table 1 shows the number of failures of the theoretical and practical questions by school. The proportions of failures of the second and third criteria of the practical evaluation for obstetrics students were $61.1 \%$ and $83.3 \%$, respectively. In the theoretical evaluation, more than
94.3\% passed all three questions. In contrast, most students from the School of Medicine passed the first practical criterion (95.3\%), and more than $71.4 \%$ of these students passed all practical performance evaluation criteria. In addition, seven (16.6\%) of 42 medicine students failed theoretical questions 1 and 3 while only one (2.3\%) failed question 2 .
In Table 2, we compared the difference between the practical ability and the knowledge observed in the two schools' students under study using Fisher's exact test. In this table, we observed that the obstetrics students showed a better understanding of the theory $(p=0.019)$, and the medical students presented better results in the practical performance evaluation $(p<0.001)$

Table 1. Did not pass according to theoretical questions and practical criteria.

\begin{tabular}{|c|c|c|c|c|c|c|c|}
\hline \multirow[b]{2}{*}{ Students } & \multirow[b]{2}{*}{$\mathbf{n}$} & \multicolumn{3}{|c|}{ Theory } & \multicolumn{3}{|c|}{ Practice } \\
\hline & & $\begin{array}{c}\text { Question } \\
1\end{array}$ & $\begin{array}{c}\text { Question } \\
2\end{array}$ & $\begin{array}{c}\text { Question } \\
3\end{array}$ & $\begin{array}{c}\text { Criteria } \\
1\end{array}$ & $\begin{array}{c}\text { Criteria } \\
2\end{array}$ & $\begin{array}{c}\text { Criteria } \\
3\end{array}$ \\
\hline \multirow[t]{2}{*}{ Medicine } & 42 & $7(16.6 \%)$ & $1(2.3 \%)$ & $7(16.6 \%)$ & $2(4.7 \%)$ & $12(28.6 \%)$ & $19(45.2 \%)$ \\
\hline & & [0.798-0.315] & [0.003-0.157] & [0.798-0.315] & [0.012-0.177] & [0.167-0.443] & [0.306-0.607] \\
\hline \multirow[t]{2}{*}{ Obstetrics } & 36 & $1(2.7 \%)$ & $1(2.7 \%)$ & $2(5.7 \%)$ & $11(17.7 \%)$ & $22(61.1 \%)$ & $30(83.3 \%)$ \\
\hline & & [0.004-0.181] & [0.004-0.181] & [0.014-0.208] & [0.175-0.477] & [0.441-0.758] & {$[0.669-0.925]$} \\
\hline
\end{tabular}

Source: data analysis.

Table 2. Comparative table of passing and failing in theory and practice by the school.

\begin{tabular}{|c|c|c|c|c|c|}
\hline \multirow{2}{*}{ Students } & & \multicolumn{2}{|c|}{ Theory } & \multicolumn{2}{|c|}{ Practice } \\
\hline & & Pass * & Not pass & Pass \$ & Not pass \\
\hline Medicine & $(n=42)$ & $28(66.7 \%)$ & $14(33.3 \%)$ & $23(54.8 \%)$ & $19(45.2)$ \\
\hline Obstetrics & $(n=36)$ & 32 (88.9\%) & $4(11.1 \%)$ & $3(8.3 \%)$ & $33(91.7 \%)$ \\
\hline
\end{tabular}

Source: data analysis. Fisher's exact test, $p$ value: ${ }^{*}=0.019$, and $\$<0.001$

\section{DISCUSSION}

We assess last academic year's health science students' ability to perform adequate positive pressure ventilation on neonatal manikins. The participants from the two schools had similar age and gender characteristics. Even that total participation was significant, we did not recruit a representative sample. Participation was voluntary and therefore it is possible that there is an overestimation effect of better-trained participants (selfselection bias). However, the academic performance of final year undergraduate students, in general, is comparable.

In this evaluation, most students had low performance since less than a quarter of them passed both the theoretical and practical assessment. These findings are similar to those of a study conducted in Ethiopia with obstetrics and nursing health workers and graduate students including gynecology and pediatrics residents ${ }^{(8)}$. In that study, Gebreegziabher et al. observed that the staff's skills were below the standard. Therefore, they concluded that the knowledge related to neonatal resuscitation was insufficient and required further training ${ }^{(8)}$.

The low performance that we observe allows us to deduce that teaching programs require reinforcing undergraduate students' competencies from the Schools of Obstetrics and Medicine to perform adequate positive pressure ventilation. We evaluated student performance at the end of the course, and some students may have learned resuscitation several months before. However, no more than six months had elapsed since the beginning of the course and the performance evaluation; therefore, we can assume a minimum rate of forgetting ${ }^{(9,10)}$.

In addition, when comparing both schools, differences were identified in the theoretical and practical scores obtained. However, other authors describe no significant difference between the profession and neonatal resuscitation skills $(8,11,13)$.

We observed that obstetrics students had better performance on the theoretical knowledge questions and lower practical assessment performance. When reviewing the courses' syllabi, we verified that the obstetrics school practices training using the Helping Babies Breathe (HBB) strategies, considered a simplified 
version of the NRP-AAP Program ${ }^{(1)}$. In contrast, the teaching of neonatal resuscitation in the School of Human Medicine prefers using the NRP-AAP program.

The HBB program implemented in countries with limited economic and logistical resources allows learning through neonatal resuscitation in primary care centers. The most critical message in training workshops is "the golden minute," emphasizing time and exercises for "continuous ventilation with a normal or slow frequency." Many reports describe this training in various studies ${ }^{(10,11,12)}$. A review on the HBB published in 2015 found that nurses more frequently use practical skills such as bag and mask ventilation in their daily routines compared to general practitioners who are not in the delivery area for that long ${ }^{(1)}$. In contrast, another study conducted in Cajamarca, Peru found no significant difference in neonatal resuscitation skills when training using HBB workshops and trained professional cadres ${ }^{(12)}$.

Likewise, other studies have reported that practical skills tend to decline without refresher training at least every nine months. This decrease in practical skills is more noticeable than the decline in knowledge received with $\mathrm{HBB}$ training ${ }^{(13)}$. The NRP-AAP program, most used for neonatal resuscitation in the School of Human Medicine, presents learning sections with more significant extensions (2) that increase knowledge retention ${ }^{(14,15)}$. However, these differences in orientation to undergraduate students in the schools are not conclusive to establish whether professional training results in the best or worst performance. The lack of uniformity in the training methods, the teachers' teaching experiences, and the resources available for training at the hospital or university headquarters also influence the results.

For practice assessment, the 88 Obstetrics students were distributed in 9 hospitals and the 163 Medicine students were distributed in 7 hospitals, assigned to different tutors and schedules. All tutors are Neonatal Health experts, but most tutors are not certified as Neonatal Resuscitation Instructors or the "Helping Babies Breathe" strategy mentors. Fur- thermore, the use of inflatable manikins and training equipment was not always available in all hospital settings.

Different realities demand adaptation of neonatal resuscitation training programs to different scenarios. For example, the algorithm for the expected flow of events during resuscitation proposed by Doctors Without Borders is aimed at low-resource countries that consider more advanced interventions that are not described in the HBB program and need further guidance ${ }^{(16)}$.

Many standardized neonatal resuscitation programs include training and addressing essential neonatal resuscitation topics. In most of those programs, standardization includes the following: providing warmth, drying and stimulating the baby, assessing his breathing, clearing his airway if necessary, and providing assisted ventilation that is effective and safe. In this way, comprehensive or standardized programs have the great potential to reduce early neonatal mortality by improving the teamwork necessary for any efficient medical practice appropriate to its reality ${ }^{(17,18)}$.

It is possible to customize the development of the capacities to care for newborns according to the competencies required by each professional group. However, it is necessary to complement their performance in real life and synchronize their training so that they can learn to work as a multidisciplinary team ${ }^{(16,17)}$. Only in this way will it be possible to improve the quality of immediate care of newborns who require respiratory support at birth ${ }^{(17,18)}$. Neonatal resuscitation is one of the strategies most likely to reduce the high neonatal mortality and morbidity observed in low- and middleincome countries ${ }^{(19)}$.

It is necessary to improve the procedural and cognitive ability of students from obstetric and medical academic schools since their acquired ability for performing PPV are ineffective six months after taking the neonatal resuscitation course in the School of Medicine. We conclude that these academic programs require reinforcing training on positive pressure ventilation, which is the cornerstone of neonatal resuscitation.
In addition, it seems necessary to complement the training in basic neonatal resuscitation at the undergraduate level, standardizing the use of equipment, manikins and simulation centers. All implemented changes must improve neonatal resuscitation teaching to undergraduate students. Likewise, it is also recommended to carry out additional training in next year after undergraduate studies, that is, during the Internship, as part of the subsequent support, to reinforce the acquisition of skills.

\section{ACKNOWLEDGEMENTS}

We appreciate the participation of the students of the Faculty of Medicine and the contribution of the members of the Neonatology Research Group of the Universidad Nacional Mayor de San Marcos.

\section{REFERENCES}

1. Niermeyer S. From the Neonatal Resuscitation Program to Helping Babies Breathe: Global impact of educational programs in neonatal resuscitation. Seminars in fetal \& neonatal medicine. 2015;20(5):300-8. DOI: 10.1016/j.siny.2015.06.005

2. American Academy of Pediatrics. Neonatal Resuscitation Program website. Available from: https:// www.aap.org/en-us/continuing-medical-education/ life-support/NRP/Pages/About.aspx [Accessed September 28, 2020].

3. Sawyer T, Umoren RA, Gray MM. Neonatal resuscitation: advances in training and practice. Advances in medical education and practice. 2017;8:11-9. DOI: 10.2147/amep.s109099

4. Sawyer T, White M, Zaveri P, Chang T, Ades A, French $\mathrm{H}$, et al. Learn, see, practice, prove, do, maintain: an evidence-based pedagogical framework for procedural skill training in medicine. Academic medicine : journal of the Association of American Medical Colleges. 2015;90(8):1025-33. DOI: 10.1097/acm.0000000000000734

5. Ávila J, Tavera M, Carrasco M. Caracteristicas epidemiológicas de la mortalidad neonatal en el Perú, 2011-2012. Rev Peru Med Exp Salud Publica. 2015;32(3):423-30. DOI: https://doi.org/10.17843/ rpmesp.2015.323.1670

6. Aziz K, Lee HC, Escobedo MB, Hoover AV, Kamath-Rayne BD, Kapadia VS, et al. Part 5: Neonatal Resuscitation: 2020 American Heart Association Guidelines for Cardiopulmonary Resuscitation and Emergency Cardiovascular Care. Circulation. 2020;142(16_suppl_2):S524-s50. DOI: 10.1161/ cir.0000000000000902

7. Caldelari M, Floris L, Marchand C, Schuler Barazzoni M. Maintaining the knowledge and neonatal resuscitation skills of student midwives 6 months after an educational program. Archives de pediatrie. 2019;26(6):385-92. DOI: 10.1016/j. arcped.2019.05.001 
8. Noor T, Raza N, Haq G. Neonatal resuscitation: a knowledge gap amongst obstetrical trainees. A cross-sectional survey amongst medical graduates of Civil Hospital Karachi. J Pak Med Assoc. 2014;64(7):856-9.

9. Carlotti AP, Ferlin ML, Martinez FE. Do our newly graduated medical doctors have adequate knowledge about neonatal resuscitation?. Sao Paulo Med J. 2007;125(3):180-5. DOI: 10.1590/ s1516-31802007000300010

10. Gebreegziabher E, Aregawi A, Getinet H. Knowledge and skills of neonatal resuscitation of health professionals at a university teaching hospital of Northwest Ethiopia. World journal of emergency medicine. 2014;5(3):196-202. DOI: 10.5847/ wjem.j.1920-8642.2014.03.007

11. Trevisanuto D, Ibrahim SA, Doglioni N, Salvadori S, Ferrarese P, Zanardo V. Neonatal resuscitation courses for pediatric residents: comparison between Khartoum (Sudan) and Padova (Italy). Paediatric anaesthesia. 2007;17(1):28-31. DOI: 10.1111/j.1460-9592.2006.02001.x
12. Cordova E, Al-Rousan T, Castillo-Angeles M, Aftab $\mathrm{S}$, Nelson BD. Effect of low-cost interventions on the retention of knowledge and skills following Helping Babies Breathe training. Int J Gynaecol Obstet. 2018;142(2):248-54. DOI: 10.1002/ijgo.12512

13. American Academy of Pediatrics. Helping Babies Breathe [Available from: http://www.aap.org/ en-us/advocacy-and-policy/aap-health-initiatives/ helping-babies-survive/Pages/Helping-BabiesBreathe.aspx]. [Accessed May 26th, 2020].

14. Bang A, Patel A, Bellad R, Gisore P, Goudar SS, Esamai $F$, et al. Helping Babies Breathe (HBB) training: What happens to knowledge and skills over time? BMC pregnancy and childbirth. 2016;16(1):364. DOI: 10.1186/s12884-016-1141-3

15. Levitt C, Kaczorowski J, Outerbridge E, Jimenez V, Connolly B, Slapcoff B. Knowledge gained following Neonatal Resuscitation Program courses. Fam Med. 1996;28(6):403-6.

16. Umphrey L, Breindahl M, Brown A, Saugstad OD, Thio M, Trevisanuto D, et al. When Helping Babies Breathe Is Not Enough: Designing a Novel,
Mid-Level Neonatal Resuscitation Algorithm for Medecins Sans Frontieres Field Teams Working in Low-Resource Hospital Settings. Neonatology. 2018;114(2):112-23. DOI: http://dx.doi. org/10.1159/000486705

17. Dempsey E, Pammi M, Ryan AC, Barrington KJ. Standardised formal resuscitation training programmes for reducing mortality and morbidity in newborn infants. Cochrane Database Syst Rev. 2015(9):Cd009106. DOI: 10.1002/14651858. CD009106.pub2

18. Thomas EJ, Williams AL, Reichman EF, Lasky RE, Crandell S, Taggart WR. Team training in the neonatal resuscitation program for interns: teamwork and quality of resuscitations. Pediatrics. 2010;125(3):539-46. DOI: 10.1542/peds.20091635

19. Doku DT, Neupane S. Survival analysis of the association between antenatal care attendance and neonatal mortality in 57 low- and middle-income countries. Int J Epidemiol. 2017;46(5):1668-77. DOI: $10.1093 / \mathrm{ije} / \mathrm{dyx} 125$ 